\title{
Differences between In-Field and Out-of-Field History Teachers Influence on Students Learning Experience in Malaysian Secondary Schools
}

\author{
Umi Kalsum Mohd. Salleh ${ }^{1}$, I Gusti Ngurah Darmawan ${ }^{2}$ \\ ${ }^{1}$ Department of Curriculum and Instructional Technology, Faculty of Education, \\ University of Malaya, Kuala Lumpur, Malaysia \\ ${ }^{2}$ School of Education, University of Adelaide, Adelaide, Australia \\ Email: umi_salleh@um.edu.my
}

Received April 2013

\begin{abstract}
The focus of this study was to investigate whether there were differences between the way in-field and out-of-field teachers in Malaysian secondary schools perceived and practiced History education, and the way their students perceived the teaching and learning of History. Both, teacher and student data were examined. A statistical analysis was conducted to validate the survey and test the relationships between variables. The results showed that there were significant differences between in-field and out-of-field teachers in the teacher characteristics of experience and student variables of classroom climate and History learning outcomes, but not on teaching approaches and methods.
\end{abstract}

Keywords: Teachers' Qualification; History Education; Measurement in Education; Teacher's Education; Learning Approaches

\section{Introduction}

History is one of the compulsory subjects in Malaysian secondary schools. Making History a compulsory subject was important in recognizing its vital role in developing a sense of belonging to one Malaysian nation. History education was recognized as a tool to infuse the ideas of belongings, the spirit of patriotism, love of country, and the commitment to the Malaysian nation. There were two practical issues in relation to the teaching of History emerged. The immediate practical problem was to have enough teachers for all the History classrooms. Since there were not enough History education graduates to fill this need, teachers unqualified in History had to be assigned to many classrooms. There was great concern that this temporary expedient would lead to a lowering of standard in the teaching of History, the very subject that was regarded as vital to the development of the emerging nation. While the National Education Blueprint (2007) aims to provide higher quality and better trained teachers in secondary school, the fact is that many teachers in Malaysian secondary schools have been required to teach subjects for which they have better prior knowledge and no prior teacher training.

Many teachers in Malaysian secondary schools were required to teach subjects for which they have better prior knowledge and no prior teacher training. Term "out-of-field teaching" refers to the practice of teaching in a subject, field or level of schooling for which a teacher has neither a major or minor tetiary qualification (McConney \& Prince, 2009). The issue of out-of-field teaching is prevalent in Malaysia, with the numbers dramatically increasing in a rapidly expanding school system. So the employment of History teachers who are not specialists in the subject of History, or are minimally qualified in this teaching area, is quite common in Malaysia. This study investi- gates the possible differences between out-of-field teachers and in-field History teachers with respect to teachers' conception of teaching, teaching approaches, and teaching methods. Moreover, this study also investigates the students' views of the classroom learning environment, learning approaches and the objectives of the teaching and learning of History.

\section{Out-of-Field Teachers}

There are several reasons why out-of-field teaching occurs in education. Ingersoll $(1998,1999,2000)$ stated that lack of agreement between is teacher teaching qualification and a teacher's teaching assignment; teachers union; and the shortages of teachers at particular field were factors that caused out-of-field teaching.

Ingersoll (2001) claimed that out-of-field teaching had been a problem in the United States but was largely unrecognized, because there was no accurate information on the situation. Ingersoll argued that secondary school teachers should have both formal education and teacher training in the subject that they taught. Since Ingersoll's (1999) early work, a number of studies have been carried out to investigate the issues surrounding outof-field teaching. Jerald (2002) used the same data as Ingersoll (1999.) His findings indicate that a high percentage of out-offield teachers teach the core subjects and not their specialized subject, in the secondary schools in the United States. He argued that this problem became much worse between the periods 1993-1994 and 1999-2000. Jerald (2002: p. 1) added that there were higher rates of out-of-field teaching in the nation's lowest-income and highest-minority schools.

Seastrom et al. (2002) defined out-of-field teaching more strictly as "a teacher without major, minor, and certification in a subject taught”. Seastrom et al.'s (2002) findings calculated the 
percentage and the number of subjects taught by out-of-field teachers in secondary schools in the United States. The subjects in the middle school with the most out-of-field teachers were in the Social Sciences, such as History, as well as Foreign Languages, English, and Mathematics. Meanwhile, in senior high schools most out-of-field teachers were assigned to teach English, Mathematics, Social Sciences, Music, Arts and Physical Education. These findings highlight that out-of-field teachers teach mostly core subjects. From this research, it appears that what these teachers tended to teach was based on the textbook. As a result, student engagement and critical thinking in the specific subject were very limited (Ingersoll, 1999: p. 29). Teaching based on the textbook could also result in difficulties in answering examination questions, because the standardized examination includes critical thinking elements (Ingersoll, 1999). Brown (2003) reported the percentages of out-of-field teaching in History and the Social Sciences in the United States. He found that 71 percent of History teachers in middle schools lacked a college minor or similar qualification in History' and a further 11.5 percent lacked a college major in History (Brown, 2003: p. 2). The percentage of out-of-field teachers in middle schools, History and Social Science subjects was slightly higher than in the high schools.

McConnel \& Price (2009b), continue researching on out-offield teaching. The research is an "assessment on the phenomenon of teaching out-of-field in Western Australia” (p. iv). They state that this study will add more information on relevant literature on this issue. The result indicates that; (a) out-of-teaching is a common and continuing practice in Australia and internationally, (b) the issue of out-of-field teaching is occurring across Western Australia (higher in the non-government schools), (c) large proportion out-of-field teachers are having at least 20 years of teaching experience (p. 96).

Another study was conducted by Dee \& Cohodes, (2008) on out-of-field teachers and students achievement. The focus of this study was to determine the relationships between subjectspecific teacher certification and academic degree to teacher quality. National Educational Longitudinal Study of 1988 (NELS: 88 cite in Dee \& Cohodes, 2008) was used in this research. The results indicate; (a) there was no significance between subjectqualified teachers with other teachers in promoting students' engagement and comfort with their subject, (b) subject-quailfied teachers were more likely to view their students pejoratively on students' homework and attentiveness, (c) the mathematics teachers reduce the achievement of the very week students (p. 29).

In a recent study carried out by Riordain \& Hannigan, (2011) investigated the level of out-of-teaching in Irish post-primary mathematics classrooms and the deployment of these teachers in Irish post-primary (second-level) school. The post-primary is a six year programme, taken by students aged $12 / 13$ to 18 years of age. The samples were 324 mathematic teachers from 51 schools, 26,634 students, and 25 principals. The researchers found that; (a) there was no significant relationship between gender and teaching qualifications, (b) older teachers were more likely to have a teaching qualification in Mathematics, (c) outof-field mathematic teachers were primarily assigned non-exam year classes compared to the qualified mathematics teachers (pp. 297-298).

In Malaysia, a research study of out-of-field teaching was carried out in 2003-2005 under a Ministry of Education research grant, the Intensified Research in Priority Areas (IRPA).
This study involved 401 teachers in their first three years of teaching experience in the classroom following the completion of their teacher education program. The study investigated the relationship between teachers' subject specialization and the subjects taught in school. The findings show that History was one of the critical subjects. Out of 17 (History teachers) respondents only five (27\%) had majored in History and 12 (73\%) of the teachers were out-of-field teachers. Thus, out-of-field teachers are prevalent in Malaysia (Aini Hassan \& Wan Hasmah Wan Mamat, 2007). Moreover, lack of subject background influences the process of teaching and learning in the classroom. According to Ingersoll (2001); "good teaching requires expertise in at least three areas; knowledge of a subject, skills in teaching and also pedagogical content knowledge” (Ingersoll, 2001: p. 34). Besides this, teacher knowledge and views about the nature of History are important because these shapes teachers' views about what they should teach in the classroom (Wilson \& Wineburg, 1988 cited in Wilson, 2001). In the present study the focus are on the differences and the similarities between outof-field and infield History teachers in relation to students' perceptions of teaching and learning History in the classroom.

\section{Methodology}

This research adopted a quantitative research survey method. The data collections were gathered by using the survey questionnaires. Two set of questionnaire were used, for teachers' and students' level. Statistics analyze such as t-test was employed to investigate the differences between in-field and out-of-field History teachers in Malaysian secondary schools In addition, the correlational research design also been employed. According to Creswell (2008) this design enables the researcher to test and describe the degree of relationship between two or more variables or sets of score. In this study, the quantitative methods were used to investigate relationships between the teachers' conceptions methods and teaching approaches, and students' approaches, to learning History, and the classroom learning climate, and History learning outcomes.

\section{Findings and Discussion}

In this study, there are two groups of teachers involve, outof-field and in-field History teachers. The independent two sample t-tests were used to compare out-of-field and in-field History teachers on the teachers characteristics (teaching experience, teaching conception, teaching approaches and teaching method) and their students' characteristics (classroom climate actual, classroom climate preferred, students' learning approaches and students' History learning outcomes).

\section{Teachers' Characteristics}

\section{TExperience (Year of Teaching)}

To investigate the differences between the out-of-field (OFT) teachers and the in-field (IF) History teachers, the two samples independent t-test was carried out. The results showed that there was a significant $(\mathrm{p}=0.002)$ difference in the average number of years teaching between the two groups of History teachers. In terms of the teaching period, the out-of-field teacher had an average of seven years and a half of teaching experience compared to the in-field teachers whom had 14 years plus of teaching experience. This suggests that in-field teachers are more experienced in teaching History compared to the 
out-of-field teachers.

\section{Teaching Conception (TCont)}

In terms of teaching conceptions, there are five dimensions used to reflect the teaching conception (TCont). Namely: AbilityDev, AttPro, KnowDeli, ExamPrep and ConDance. Table 2 shows the comparison between the in-field (IF) and the OFT History teacher for the five dimensions. The results show that there were no significant differences between the two groups for four out of five dimensions tested, the only significant difference was found in ConDance (conduct guidance). ConDance is one of the dimensions in teaching conception. This dimension is measuring the teachers' influence as role model in the classroom. In-field teacher reported a higher level of ConDance. This indicates that the in-field teacher had a higher level of presenting a good role model of conduct to the students compared to the out-of-field teacher.

\section{Teaching Approach (TApp)}

There were two scales used to measure the constructs of teaching approaches (TApp), namely: conceptual change/student-focused (CCSF) and information transmission/teacherfocused (ITTF) scale. They are labeled as TConChan and TInfoTrans respectively. Even though the differences were not significant for either scale, the patterns are worth mentioning. In general, in-field teachers focused more on conceptual change and less on the information transfer compared to the out-offield teachers.

\section{Teaching Method (TMet)}

Effective teaching (TEff) and active teaching (TAct) were the two constructs used to reflect the teaching method (TMet). The results show that there is no significant difference in the use of active teaching methods even though in general in-field teachers had a slightly higher average. However, the results from t-test shows that the in-field teachers had a significantly higher level of effective teaching being used in their classroom $(p=0.004)$.

\section{Student Characteristic}

\section{Classroom Climate Preferred (CCP)}

There were five dimensions used to reflect the preferred climate of History classrooms climate (CCP), namely: investigation (INV), personalization (PERSO), participation (PARTI), independent (IND) and differentiation (DIFFER). The comparisons between the in-field and the out-of-field History teacher on the five dimensions are tested using t-test. Out of the five dimensions tested, four of them showed significant differences between the two groups, investigation (INV), personalization (PERSO), participation (PARTI) and differentiation (DIFFER). This result indicates that students under in-field teachers preferred to have classrooms with higher levels of investigation (INV), personalization (PERSO), participation (PARTI) and differentiation (DIFFER). For the fifth dimension, the independent (IND), the differences were not significant.

\section{Classroom Climate Actual (CCA)}

Similar to CCP in the classroom climate actual (CCA), there were five dimensions used to reflect the actual History classroom climate (CCA), namely: investigation (SInv), personalisa- tion (SPer), participation (SPar), independent (SInd) and differentiation (SDiffer). Out of five dimensions tested, only one of the dimensions was significantly different between the two groups. The personalization (SPer) showed a significant difference ( $p=$ 0.002 ), indicating that students under in-field teachers experience more personalized activities in the classroom. For the rest of the dimensions, there were no significant differences; however, the patterns are worth mentioning; with the results suggesting that students under out-of-field teachers were experience more investigation, independent, participative and differrentiate activities in the classroom.

\section{Learning Approaches (Learning)}

The results show the comparison between the in-field (IF) and the out-of-field (OFT) History teacher for the six constructs, namely: students' surface motive (SSM), students' surface strategy (SSS), students' achieving motive (SAM), students' achieving strategy (SAS), students' deep motive (SDM), and students' deep strategy (SDS). There were no significant differences on any of these constructs, showing that in general students under in-field and out-of-field are showing very similar approaches to learning,

\section{Students Learning Outcome (SOUTCOME)}

There are three constructs used in the student learning outcome (SOUTCOME) namely Country (SContry), Community (SComm) and Individual (SIndividual). There were no significant differences found for the three constructs.

\section{Discussion}

The t-test analysis was used to examine the differences between out-of-field teachers and in-field teachers. On most of the variables tested, there were no statistically significant differences between in-field and out-of-field History teachers in Malaysia. The only four variables in which the differences proved significant were teacher experience, the teaching conception of conduct guidance, the dimensions of personalization (PERSO), participation (PARTI), independent (IND) and differentiation (DIFFER) in the students preferred classroom climate, and the dimension of personalization in the students' actual classroom environment.

In relation to teacher experience (measured in years of teaching) the results indicated that out-of-field History teachers were less experienced compared to the in-field teachers. Outof-field History teachers had less experience, an average of 7 years of service, compared to the 14 years for in-field teachers. The finding would seem to consistent with the school context in Malaysia. As student numbers have increased, and schools have needed more History teachers, there has been a tendency to make use of less experienced members of staff as out-of-field history teachers. Staffs with more experience are more likely to be teaching in the area of their training specialization, in this case upper level History.

Of the five dimensions of teachers' teaching conceptions employed, only the conduct guidance (ConDance) conception, which previous studies had identified as an important aim of teaching (e.g. Goa \& Watkins, 2001; Pratt, 1992; Fox, 1983), showed significant difference between in-field and out-of-field teachers. This result indicated that in-field teachers, whom the previous results have shown to be the more experienced teachers, were more likely to be committed to nurturing the personal 
conduct of their students through their History teaching.

In terms of preferred classroom climate, there was a significant difference between students of in-field teachers and those of out-of-field teachers on four out of the five dimensions. This means that students under in-field teachers preferred classrooms where they experience investigation, personalization, participation, and differentiation. On the fifth dimension of independence there was no difference between the two groups of students, suggesting that the authority of the teacher in the classroom was recognized, whether they were fully qualified or not.

In the actual students' classroom climate (CCA), out of five dimensions used for this factor, only personalisation showed any significant difference between students under the two groups of teachers, with students of in-field teachers experiencing greater personalisation. This result can be explained by the greater experience of in-field teachers in the Malaysian context. In particular, they are more likely to have been teaching longer in the same school and even to have taught the same class for two or more years. They thus have had a greater opportunity to gain personal understanding of the students they are teaching. It is possible, that out-of-field teachers who were younger and less experienced, would be able to develop a more personalised dimension to their classrooms, as they gain more familiarity with the History syllabus and get to know the students in their classes better. An out-of-field teacher whose efforts are concentrated on subject content which is new to them, has less time to focus on understanding students' needs and interests. The chance for professional development in the teaching of History may help them to become more familiars with the content and assessment, so that they are able to direct more of their attention to the individual students in their class.

There were four variables which showed no significant difference on the t-test results in this study, namely; teachers' teaching approach, teaching method, students' approaches to learning, and learning outcomes. This is an important finding itself in that it indicates not only that in-field and out-of-field teachers were using much the same teaching approaches and methods, but also that the students under each group of teachers were adopting similar approaches to learning and perceived much the same learning outcomes in their history classroom. These results can be seen to be consistent with expectations that teachers in Malaysia are expected to follow the set of objectives and lesson plans laid out in the history syllabus. In addition, out-of-field teachers are after all fully trained in another area of specialization and can be expected to adapt their knowledge and teaching skills to the teaching of History.

\section{Conclusion}

To conclude, comparison between out-of-field and in-field on students' and teachers' characteristic and perceptions are also discussed in this chapter. The results show that the in-field teachers had more experience in teaching History compared to the out-of-field teachers. In term of teaching conception, the ConDance (conduct guidance) dimension was found to differ significantly, but not other dimensions. This indicates that the in-field teacher had a higher level of presenting a good role model of conducting to the students compared to the out-of-field teacher. In addition, the results reported that students under in-field teachers preferred to have classrooms with higher level of investigation (INV), personalization (PERSO), participation
(PARTI) and differentiation (DIFFER) activities. Meanwhile, in the actual classroom the personalization (SPer) dimension was found to differ significantly, indicating that students under in-field teachers employ the personalisation activities at higher level in the actual classroom climate compared to the out-offield History teachers.

In general, the findings have developed our knowledge on the issue of out-of-field teaching in the learning process, in particular in History teaching. Much literature had focused on the macro impact of out-of-field teachers on teaching at the school or state level. What remained unclear was how teachers with out-of-field qualifications actually taught in the classroom, and whether there were any differences in students' learning between classes taught by out-of-field and in-field History teachers. This study has improved our understanding by pinpointing the importance of teachers' experience, conduct guidance as a conception of History teaching, personalization in the classroom climate and students' History learning outcomes, as defined by the syllabus objectives. In relation to all the above variables, there were differences between in-field and out-of-field teachers.

The phenomenon of out-of-field teaching is still prevalent in education and has stimulated many researchers to investigate this issue. However, this is the first study in the field conducted in Malaysia. Although there are differences between schools in the various states and rural regions which may affect the application of these Kuala Lumpur findings to other parts of Malaysia, some useful implications can be drawn for the teaching of History generally at secondary level in Malaysia. In addition, the findings can be used as a basis for future research.

Furthermore, this study has provided empirically based analytical procedures for testing and extending existing frameworks and models of the relationships between the many variables which can impact on and interact with classroom learning and teaching in general. Overall, these findings provide a better understanding of the relationships between out-of-field qualifications and other teacher and student factors in the process of learning in History in the Malaysian classroom.

\section{REFERENCES}

Aini, H., \& Wan Hasmah, W. M. (2007). Mengajar di luar bidang pengkususan: Sejauh manakah seriusnya masalah ini di Malaysia? (Outof-field teaching: How series this problems in Malaysia?) Jurnal pendidikan, Jilid, 27, 149-163.

Brown, S. D. (2003). State certification requirements for history teachers. ERIC Digest (ERIC Document Reproduction Service No ED482210).

Dee, T. S., \& Cohodes, S. R. (2008). Out-of-field teachers and students achievement: Evidence from matched-pairs comparisons. Public Finance Review, 36, 7-32.

Fox, D. (1983). Personal theories of teaching. Studies in Higher Learning, 8, 151-163.

Gao, L., \& Watkins, D. (2002). Conceptions of teaching held by school science teachers in P.R. China: Identification and cross cultural comparisons. International Journal of Science Education, 74, 61-79.

Ingersoll, R. M., \& Merrill, E. (2011). The status of teaching as a profession. In J. Ballantine, \& J. Spade (Eds.), Schools and society: A sociological approach to education (pp. 185-189). (4th ed.). CA: Pine Forge Press: Sage Publications.

Ingersoll, R. M. (1998). The problem of out-of-field teaching. Phi Delta Kappan, 79, 773-776.

Ingersoll, R. M. (1999). The problem of unqualified in America secondary school. Educational Researcher, 28, 26-37. http://dx.doi.org/10.3102/0013189X028002026 


\section{U. K. M. SALLEH, I. G. N. DARMAWAN}

Ingersoll, R. M. (2000). Out-of-field teaching. ERIC Digest (ERIC Document Reproduction Service No ED449119).

Ingersoll, R. M. (2001). Rejoinder: Misunderstanding the problems of out-of-teaching. Educational Researcher, 30, 21-22.

http://dx.doi.org/10.3102/0013189X030001021

Jerald, C. (2002). All talk, no action: Putting an end to out-of-field teaching. (ERIC Document Reproduction Service No ED468741).

McConney, A., \& Price, A. (2009a). An Assessment of the Phenomenon of "Teaching Out-of-Field" in WA Schools: Final Report. Perth, WA: Western Australian College of Teaching (WACOT).

Pratt, D. D. (1992). Conceptions of teaching. Adult Educational Quar- terly, 42, 203-320.

Riordain, M. N., \& Hannigan, A. (2011). Who teaches mathematics at second level in Ireland? Irish Educational Studies, 30, 289-304. http://dx.doi.org/10.1080/03323315.2011.569117

Seastrom, M. M., Gruber, K. J., Henke, R., McGrath, D. J., \& Cohen, B. A. (2002). Qualification of the public school teacher workforce: Prevalence of out-of-field teaching, 1987-88 to 1999-2000. Statistical analysis report (ERIC Document Reproduction Service No ED468740).

Wilson, S. M. (2001). Research on history. In V. Richardson (Ed.), Handbook of research on teaching (4th ed.). (pp. 527-544). New York: Macmillan. 